\title{
Understanding the trade-offs in tropical reservoir fishery in a socio-ecological perspective
}

\author{
THANKAM THERESA PAUL ${ }^{1}$, S. MANOHARAN ${ }^{1}$, SHYAM S. SALIM ${ }^{2}$, K. R. SREENATH ${ }^{2}$, \\ U. K. SARKAR ${ }^{1}$, ASHA LANDGE ${ }^{3}$ AND B. K. DAS ${ }^{4}$ \\ ${ }^{I}$ Research Centre of ICAR-Central Inland Fisheries Research Institute, CMFRI Campus, Ernakulam North P.O. \\ Kochi - 682 018, Kerala, India \\ ${ }^{2} I C A R$-Central Marine Fisheries Research Institute, Ernakulam North P.O., Kochi - 682 018, Kerala, India \\ ${ }^{3} I C A R$-Central Institute of Fisheries Education, Versova, Mumbai - 400 061, Maharashtra, India \\ ${ }^{4} I C A R$-Central Inland Fisheries Research Institute, Barrackpore, Kolkota - 700 120, West Bengal, India \\ e-mail: thankamtheresa@gmail.com
}

\begin{abstract}
A study involving the assessment of ichthyo-diversity, physico-chemical aspects of reservoir, socio-economics of the reservoir fishers and their sustainability issues was conducted in Peechi Reservoir, in Thrissur District, Kerala, India during 2016-2018. The study indicated the need for developing appropriate reservoir based fishery management measures in protected ecosystems considering the intricate trade-offs between conservation strategies leading to ensuring livelihoods for the resource poor fishers. Fish and water samples collected were analysed on various scales. The study indicated that Salmostoma novacula was the major species contributing to the diversity in terms of abundance in the reservoir. The diversity, species evenness ( 0.92 to 0.95$)$ and species richness index (1.73 to 2.39) were observed to be higher at the sampling site 'Intermediate 1'. Canonical correspondence analysis (CCA) indicated that diversity was positively associated with dissolved oxygen (0.58), $\mathrm{pH}(0.62)$ and hardness $(0.66)$ and negatively correlated with conductivity (-0.60). Socio-economics of the reservoir fishers identified very low monthly relative contribution of the species to the fishers' income of the reservoir, which calls for better management measures of the reservoir with respect to supporting the livelihood and sustainable management. Based on fishers' perception on fisheries management, an index called reservoir fisheries management index (RFMI) was introduced, which indicated that management of technical drivers will ensure better fisheries in Peechi Reservoir. The study identified that technological interventions like enclosure-based culture system using indigenous fishes of the reservoir such as Etroplus suratensis, hatchery operations and tourism during the lean period to support the livelihood of the fishers are critically needed. Thus, a participatory mode of culture supported sustainable conservative management may be incorporated in this reservoir. This is the first study of its kind in reservoir based aquatic system.
\end{abstract}

Keywords: Fish diversity, Participatory mode, Reservoir management, SIMPER, Socio-economics

\section{Introduction}

The dynamic and diverse tropical freshwater ecosystems are abode to more than 10,000 species of fish (Nelson, 1994), despite being the most stressed (McIntyre et al., 2016) aquatic system. Reservoirs (Dudgeon et al., 2006) were not primarily constructed for fisheries purposes, but for water development projects such as hydroelectric power generation and agricultural irrigation. Various researchers have studied reservoirs in a fisheries perspective (Fernando and Holcík, 1991; Agostinho et al., 1997). Thomas and Abdul Azis (1999), Jyotishi and Parthasarathy (2007) and Tasneem (2011) studied the fishery management aspects of Indian reservoirs. These studies revealed that though fishing and fisher livelihoods remain a low priority activity in Indian reservoirs, they continue to remain as the mainstay in the livelihood sustenance of the underprivileged communities, as a meaningful employment for augmenting income.

Understanding the spatial and temporal fish assemblage structure in tropical reservoirs is relevant, when reservoirs are used as a potential aquatic ecosystem for fish production. In this scenario, studies concerning fish associations may be considered mandatory for the sustainable management of the tropical reservoir ecosystem. But successful management of any reservoir depends on the comprehension of species diversity and knowledge about the associated community and their participation in the management activities. Fishers should be considered the primary stakeholders in developing plans and policies for enhancing the productivity of any fisheries. Scarce information on reservoir fishers hampered the chance of developing sustainable and integrated management measures (linkages between the 
socio-economic and the environmental dimensions) within fisheries (Liswanti et al., 2012; Braveman and Gottlieb, 2014). Realising that the fishers' perception on fisheries management plays a pivotal role in chalking out policies, programmes and plans, an index called reservoir fisheries management index (RFMI) was introduced in this study.

Peechi Reservoir is one of such numerous tropical reservoirs which was not primarily constructed for fisheries purposes, but could serve as a potential water body for fish production in the near future. The present study was taken up in Peechi Reservoir in Thrissur District of Kerala, India with the objective of developing appropriate reservoir based fishery management module in protected ecosystems considering the intricate trade-offs between mandatory ichthyo-faunal conservation strategies and livelihood assurance for the resource poor fishers.

\section{Materials and methods}

Study area

Peechi Reservoir (Fig. 1), a medium reservoir built across Manali River was constructed in 1957. This artificial tropical lake having a catchment area of 1300 ha is situated in Thrissur District of Kerala and geographically located between $10.51^{\circ} \mathrm{N}, 76.39^{\circ} \mathrm{E}$ and $10.55^{\circ} \mathrm{N}, 76.391^{\circ} \mathrm{E}$. Multiple stakeholders are involved in the management of the reservoir. The fisheries and allied activities of the reservoir are effected through Peechi SC/ST Co-operative Society. Nearly 200 people are registered members in the co-operative society. Around $20 \%$ of the registered members are active regular fishers whose primary source of income is fishing.

For the present study, Peechi Reservoir was divided into three zones $i$. e . lentic (near to the shutter of the dam), lotic (riverine region) and intermediate zones (between lentic and lotic zones). This sampling strategy was carried out to conduct an in-depth investigation into the hydro-biological variables of this system ensuring an unbiased sampling. Fig. 1 clearly depicts the extent of the reservoir and its connectivity to Manali River and its tributaries at two sites, Lotic 1 and Lotic 2. Lotic zones were predominantly riverine ecotones. The lentic zone (lacustrine region) which was designated as Lentic 1 had no direct connection with the river. In order to ensure unbiased sampling, three sampling sites namely Intermediate 1, 2 and 3 were selected from intermediate zone for the current investigation.

\section{Sampling details}

Monthly samples of water and fish were collected from Peechi Reservoir during 2016 to 2018. The physical characteristics of water such as temperature, $\mathrm{pH}$,

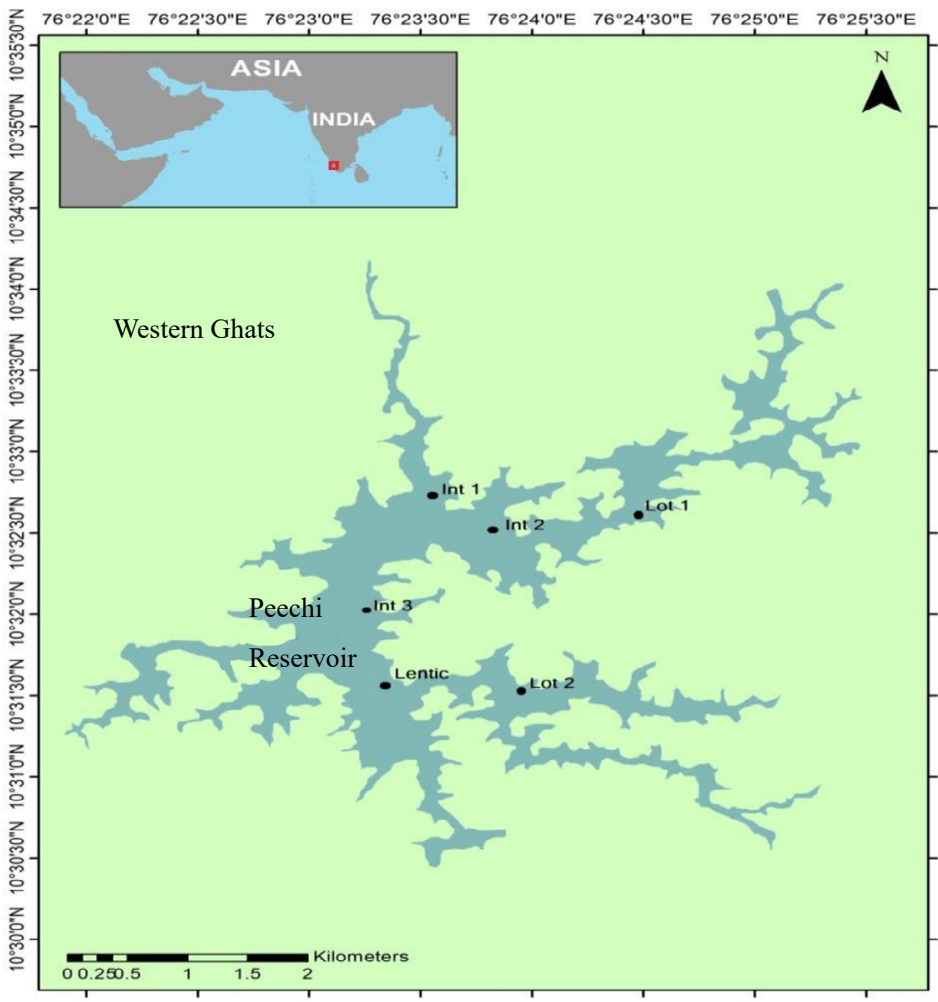

Fig. 1. Satellite image of Peechi Reservoir 
conductivity and transparency were measured in situ using Eu-tech multi-parameter probe. The chemical characteristics of water such as alkalinity, dissolved oxygen (DO) and hardness were measured using titrimetric method (APHA, 2012). Nutrients were determined using spectrophotometric method (APHA, 2012). Monthly fish samples were collected from pre-identified sampling sites in the reservoir by experimental fishing using gillnets (mesh sizes ranging from 20 to $120 \mathrm{~mm}$ ) and from the landings at the co-operative society site. Fish specimens thus collected were taxonomically identified using Talwar and Jhingran (1991). The spatial data of fish were segregated into three zones as mentioned above and analysed. The temporal data of fish were analysed by segregating the data into three seasons vis-a-vis pre-monsoon (February-May), monsoon (June-September) and post-monsoon (October- January).

A reconnaissance survey was carried out to extract details on the socio-economic profile of the fishers of Peechi Reservoir. The prepared schedule extracted information related to demographic information, fisheries, economics and marketing aspects and the various strategies suggested for better management of the fishery in this reservoir were scored based on the method of Garett and Woodsworth (1969). The sample size for socio-economic survey was $20 \%$ of the registered members, who were active regular fishers whose primary source of income is fishing. The study segregated the statements provided by fishers for scoring into five drivers (social, technical, economical, institutional and policy drivers) in a fisheries perspective. Each of these drivers had various attributes which were scored on a five point continuum. The continuum addressed the fishers perception on merit, with 5 (strongly agree), 4 (agree), 3 (no opinion), 2 (disagree) and 1 (strongly disagree). Based on the scores provided for each attribute, the cumulative scores were computed for the drivers. Reservoir fishery management index (RFMI) was thus devised as a composite index of all these five drivers. This composite index provided the fishers perception on the priorities for the reservoir fisheries management with fisher participation.

The present study used the statistical package for community ecology and environment namely PRIMER 7.0 (Clarke and Gorley, 2015) for analysing species data and $\mathrm{R}$ for statistical computing and graphics (R Core Team, 2020). ArcGIS Desktop 10.0 was used in the mapping of diversity indices on a GIS platform (Biswas et al., 2016).

\section{Data analysis}

Biodiversity indices, namely Pielou's evenness index, Margalefs richness index and Shannon-Weiner's diversity index were used to estimate the discrepancy of fish communities in this system. ANOVA was carried out to determine whether there existed any statistically significant differences of the means of biodiversity indices between the sampling zones. The temporal and spatial dominance curve across three seasons and three zones were plotted separately using PRIMER 7.0 to find the rate of instability of the system on temporal and spatial scale respectively. Similarity Percentage (SIMPER) analysis was carried out using PRIMER 7.0 on a temporal and spatial scale to identify the species and zone contributing to the diversity of Peechi Reservoir. Canonical correspondence analysis (CCA) was carried out between the hydrological variables and fish assemblage (TerBraak and Smilauer, 2002) to identify the predominant variables impacting the fish assemblages in Peechi Reservoir. Conservation status and fish production scenario of the reservoir was identified from the IUCN listing of fishes (IUCN, 2017) and State fisheries department respectively. Catch composition studies of Peechi Reservoir helped to identify the major single species which formed a fishery in the reservoir. Livelihood analysis was carried out to identify the stability of fishers' income for a sustainable livelihood. The most contributing driver was identified and was recommended as the best management practice that can be adopted for this reservoir.

\section{Results and discussion}

\section{Spatial dimension of ichthyodiversity}

The diversity studies in Peechi Reservoir recorded 14 species belonging to 11 genera, 6 families and 3 orders. Paul et al. (2017) recorded 18 species belonging to 15 genera, 10 families and 4 orders from this reservoir. Table 1 presents the fish species in Peechi Reservoir during the present study. Table 2 depicts the spatial variation in ichthyo-diversity indices such as Shannon diversity index, Margalef's species richness index and Pielou's species evenness index across various zones in Peechi Reservoir. The results of ANOVA for the diversity indices indicated that there existed significant difference between the means of Pielou's species evenness index in three zones. Spatial distribution of diversity in terms of abundance (Table 2) indicated that the number of species is more in the lotic zone (Lotic 2) compared to all other zones. This indicated that the feeder riverine system (tributaries of Manali River) was a major source of ichthyo-diversity in Peechi Reservoir due to its inherent conditions supporting the ingestion of allochthonous food resource into the reservoir system. Hence these zones (Lotic 1and 2) provided suitable feeding (Nogueira et al., 2010) and breeding (Hye and Alamgir, 1992) grounds for the fishes in the system and thereby exhibited greater fish diversity.

The diversity, species evenness (0.92 to 0.95$)$ and species richness indices (1.73 to 2.39) were observed to 
Table 1. Fish species recorded from Peechi Reservoir

\begin{tabular}{|c|c|c|c|c|}
\hline No. & Families & Species & $\begin{array}{l}\text { Conservation status } \\
\text { (as per IUCN Red List) }\end{array}$ & Population trend \\
\hline 1 & Cyprinidae & Puntiu smahecola & Endangered & Unknown \\
\hline 2 & & P. chola & Least Concern & Unknown \\
\hline 3 & & P. sophore & Least Concern & Unknown \\
\hline 4 & & Salmostoma novacula & Least Concern & Unknown \\
\hline 5 & & Rasbora dandia & Least Concern & Decreasing \\
\hline 6 & & Pethia punctata & Least Concern & Stable \\
\hline 7 & & Garra mcclellandi & Data Deficient & Unknown \\
\hline 8 & & Devario malabaricus & Least Concern & Stable \\
\hline 9 & Aplocheilidae & Aplocheilus lineatus & Least Concern & Decreasing \\
\hline 10 & Percidae & Etroplus maculatus & Least Concern & Stable \\
\hline 11 & & Etroplus suratensis & Least Concern & Decreasing \\
\hline 12 & Gobiidae & Glossogobius giuris & Least Concern & Unknown \\
\hline 13 & Bagridae & Mystus malabaricus & Endangered & Decreasing \\
\hline 14 & Siluridae & Ompok malabaricus & Endangered & Unknown \\
\hline
\end{tabular}

Table 2. Spatial variations in diversity indices in Peechi Reservoir

\begin{tabular}{llllll}
\hline Zones & Species & No. of species & $\begin{array}{l}\text { Margalef's species } \\
\text { richness index }\end{array}$ & $\begin{array}{l}\text { Pielou's species } \\
\text { evenness index }\end{array}$ & Shannon's diversity index \\
\hline Lotic 1 & 12 & 363 & 1.87 & 0.80 & 2.00 \\
Lotic 2 & 13 & 608 & 1.87 & 0.70 & 1.80 \\
Intermediate 1 & 11 & 66 & 2.39 & 0.95 & 2.27 \\
Intermediate 2 & 9 & 72 & 1.87 & 0.92 & 2.02 \\
Intermediate 3 & 9 & 103 & 1.73 & 0.93 & 2.05 \\
Lentic & 7 & 64 & 1.44 & 0.88 & 1.71 \\
\hline
\end{tabular}

be higher in 'Intermediate 1' which may be due to mixing of riverine and lacustrine fish species in these zones. Oliveira et al. (2005) attributed the high spatial heterogeneity in intermediate zones to the presence of macrophytes and woody debris which provided suitable substratum for colonisation of planktonic organisms which form a food resource for many species in the intermediate zone. The Lentic zone had the lowest spatial heterogeneity of fishes. This finding may be attributed to the unconducive habitat for fish assemblage in these zones on account of subsidised food ration (Doi et al., 2008) brought in by feeder rivers. Similar results were reported by Joy and Death (2004) wherein species diversity was found increasing towards the riverine (lotic) zone.

\section{Temporal dimensions of ichthyodiversity}

Table 3 shows that the number of species recorded was maximum (14) during monsoon compared to other seasons. Miranda (2001) explained that the predominance of monsoon-based ichthyo-diversity (14) in Peechi may be due to the increase in food and shelter contributed by flooded vegetation in the reservoir. Decrease in lacustrine water levels (due to scarce rainfall and high water temperature) indirectly resulted in the concentrations of fish populations (Agostinho et al., 2007) leading to the high values (2.53) of species richness index during post-monsoon (Miranda, 2001).

\section{K-dominance curves}

Spatial and temporal dominance plot was prepared to identify any dominant fishery in Peechi in the spatial and temporal scales. Temporal K-dominance curve (Fig. 2) of the reservoir indicated highly diverse pre-monsoon season with dominance percentage of single species less than $30 \%$ and an unstable post-monsoon. Further, the spatial K-dominance study (Fig. 3) indicated that Intermediate 1 zone was the most stable ecotone in the reservoir with no clear dominance by any single species. The stability may be attributed to the intermixing of species in these zones as it provided suitable habitat with macro-aquatic vegetation. The most unstable zone was Lotic 2 zone as indicated by $50 \%$ of the single dominant species in the system.

\section{SIMPER analysis}

Temporal analysis (Table 4) indicated the endemism and dominance of the species Salmostoma novacula followed by Puntius mahecola in Peechi across all 
Table 3. Temporal variations in diversity indices in Peechi Reservoir

\begin{tabular}{lllll}
\hline Season & No. of species (s) & Margalef's species richness index (d) & Species evenness (J') & Shannon's diversity index (H') \\
\hline Post-monsoon & 13 & 2.53 & 0.83 & 2.24 \\
Monsoon & 14 & 2.46 & 0.80 & 2.26 \\
Pre-monsoon & 13 & 2.37 & 0.84 & 2.27 \\
\hline
\end{tabular}

Table 4. Percentage contribution of species on temporal scale in Peechi Reservoir

\begin{tabular}{llllllll}
\hline Percentage species contribution (Temporal scale) & & & \\
\hline Season & Similarity & Species & $\%$ & Dissimilarity between & $\%$ & Major species & $\%$ \\
\hline Post-monsoon & 77.75 & S. novacula & 14 & Monsoon and post-monsoon & 24.69 & Pethia punctata & 15.84 \\
Monsoon & 77.04 & S. novacula & 14.8 & Post-monsoon and Pre-monsoon & 19.95 & P. punctata & 13.60 \\
Pre-monsoon & 83.12 & S. novacula & 15.02 & Monsoon and Pre-monsoon & 18.29 & P. punctata & 15.97 \\
\hline
\end{tabular}

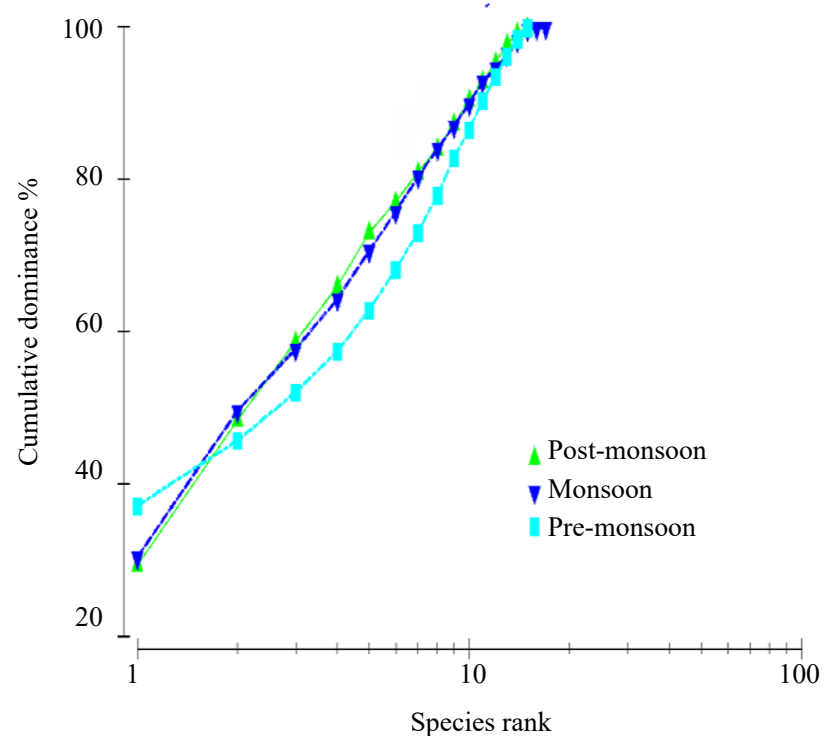

Fig. 2. Dominance plot (Temporal scale)

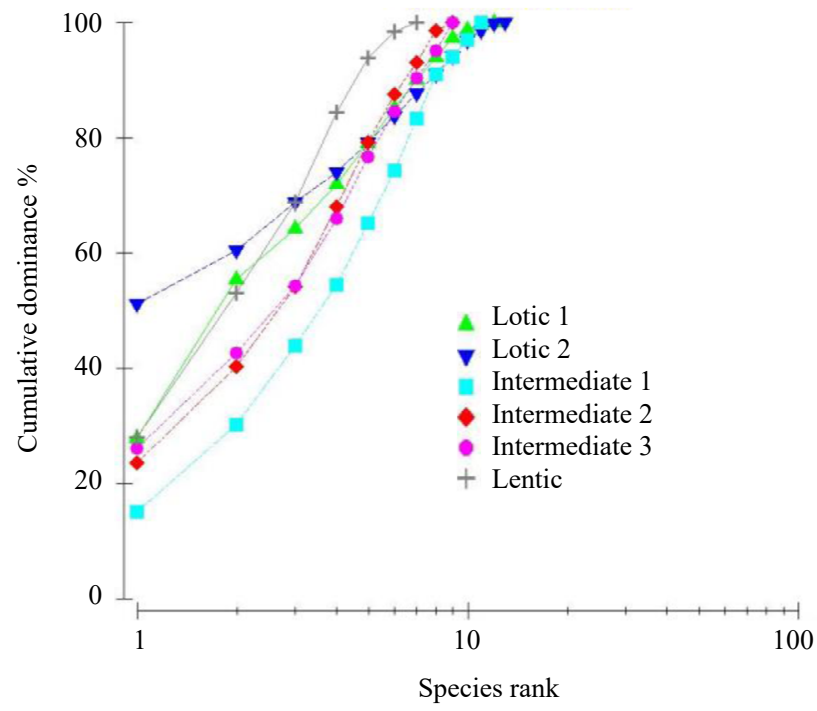

Fig. 3. Dominance curve (Spatial scale) seasons. The study also indicated that Pethia punctata $(15.84 \%)$ contributed maximum to dissimilarity in terms of abundance on a temporal scale and also reflected the season specific endemism of Etroplus suratensis and Rasbora dandia in the reservoir. Similarly, spatial SIMPER analysis indicated that $S$. novacula $(32.9 \%)$ was dominant in the lotic zone where as $P$. mahecola was predominant in the intermediate zone to the tune of $18.81 \%$ (Table 5). This clearly explained the dominance and endemism of $S$. novacula in the lotic zone across all seasons. The dominance of $P$. mahecola in intermediate zone was explained by its contribution to the dissimilarity in species abundance between the Lentic and Intermediate zones across all seasons (Table 5).

\section{Canonical correspondence analysis (CCA)}

Canonical correlation studies (CCA) between species diversity and hydrological variables indicated that dissolved oxygen, $\mathrm{pH}$, hardness and conductivity influenced the fish diversity in Peechi (Fig. 4). Eigen values and percentage of CCA in Peechi Reservoir was 0.146 (axis 1) and 0.119 (axis 2) explaining 35.92 and $29.2 \%$ of the variance between the variables in the components. The first canonical loading (Table 6) was positively associated with dissolved oxygen $(0.58), \mathrm{pH}$ (0.62) and hardness (0.66) and negatively correlated with conductivity $(-0.60)$. The study showed that these variables contributed maximum to the first canonical variable and hence most associated with variation in species abundance.

Fig. 4 indicates that majority of the species exhibited wide distribution patterns. Species like Pethia punctata and Devario malabaricus indicated lower abundances (density $<1.0 \%$ ) and a limited distribution. The herbivorous feeding habit of Garra mcclellandi and its occupancy in ecological niche as a bottom feeder substantiated the results of CCA. Aplocheilus lineatus inhabited bentho-pelagic ecological niche of the reservoir 
Table 5. Percentage contribution of species on spatial scale in Peechi Reservoir

\begin{tabular}{llllllll}
\hline \multicolumn{2}{l}{ Percentage species contribution (spatial scale) } \\
\hline Similarity in groups & Similarity & Species & $\%$ & Dissimilarity between & $\%$ & Major species & $\%$ \\
\hline Lotic & 63.23 & S. novacula & 32.9 & Lotic and Intermediate & 81.9 & S. novacula & 41.51 \\
Intermediate & 67.08 & P. mahecola & 18.8 & Lotic and Lentic & 84.8 & S. novacula & 41.25 \\
& & & & Intermediate and Lentic & 66.1 & P. mahecola & 17.17 \\
\hline
\end{tabular}

Table 6. Summary of CCA values and Eigen values of data for biotic and abiotic factors of Peechi Reservoir

\begin{tabular}{lll}
\hline Variables & CCA I & CCA II \\
\hline Water temperature $\left({ }^{\circ} \mathrm{C}\right)$ & 0.06 & -0.27 \\
Depth $(\mathrm{m})$ & -0.07 & 0.26 \\
Transparency $(\mathrm{m})$ & 0.07 & -0.25 \\
Dissolved oxygen $(\mathrm{ppm})$ & 0.58 & -0.08 \\
Conductivity $(\mu \mathrm{S})$ & 0.22 & -0.60 \\
$\mathrm{pH}$ & 0.62 & -0.26 \\
Hardness $(\mathrm{ppm})$ & 0.66 & 0.21 \\
Alkalinity $(\mathrm{ppm})$ & -0.13 & -0.46 \\
Nitrate $(\mathrm{ppm})$ & 0.01 & -0.38 \\
Phosphate $(\mathrm{ppm})$ & 0.15 & 0.15 \\
Silicate $(\mathrm{ppm})$ & 0.17 & -0.03 \\
Eigen values & 0.1464 & 0.119 \\
Percentage & 35.92 & 29.2 \\
\hline
\end{tabular}

(Froese and Pauly, 2018), which substantiated the species abundance relative to the reservoir depth (Fig. 4). Etroplus suratensis exhibited their breeding behaviour in shallow depths where oxygen was abundant between lotic and intermediate zones in the reservoir.

\section{Conservation status of fishery in Peechi Reservoir}

The assessment of conservation status of ichthyo-diversity in Peechi Reservoir is relevant in order to envisage the level of conservation to be implemented in this reservoir. The study indicated that $75 \%$ of species were in the "Least Concern" category, $18.75 \%$ in "Endangered" and 6.25\% in "Data Deficient" category of the IUCN (IUCN, 2017). Species such as Devario malabaricus, Rasbora dandia and Etroplus suratensis were reported of exhibiting decreasing population trends. Species such as Ompok malabaricus and Mystus malabaricus were included under 'Near Threatened' category (Table 1). Salmostoma novacula was a least concerned species indicating the possibility of sustainable exploitation of the species.

The study further showed that the contribution of miscellaneous fish species (Fig. 5) which include S. novacula and P. mahecola to the fishery of Peechi Reservoir. This shift in the catch from Indian major carps (IMC) to $S$. novacula and $P$. mahecola may be due to the use of small meshed gears. The catch composition study

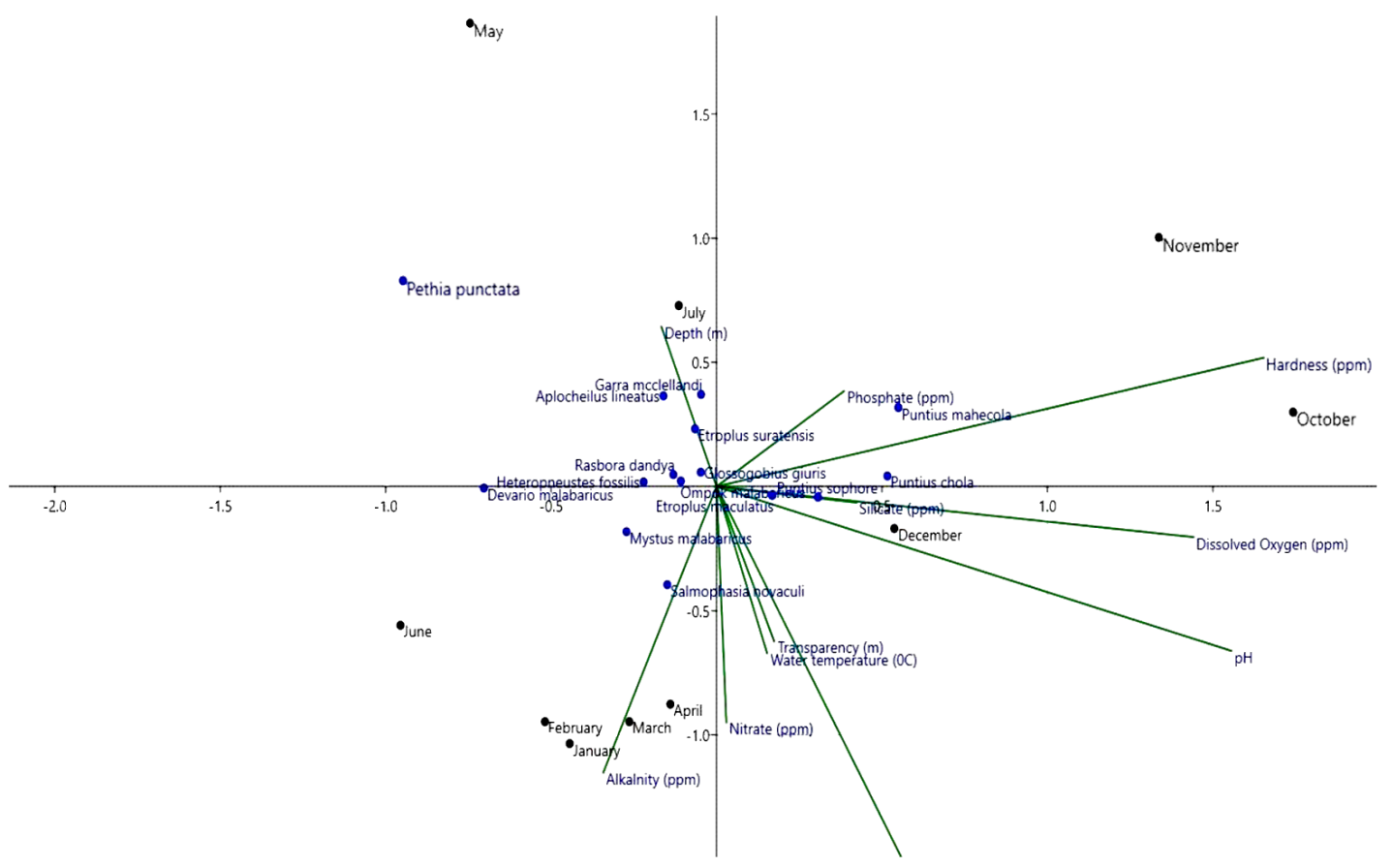

Fig. 4. Ordination diagram of CCA showing relationship between the hydrological variables and species diversity in Peechi Reservoir 


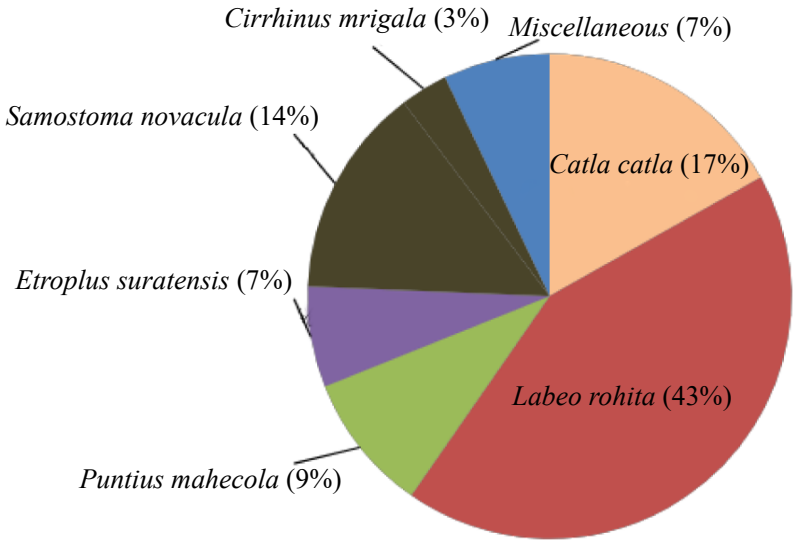

Fig. 5. Catch composition of Peechi Reservoir during 2016-2018

of Peechi Reservoir indicated that $S$. novacula contributed to $14 \%$ of the catch whereas the endangered Puntius mahecola (Fig. 5) contributed to $9 \%$. The study indicated a need for regulating the fishery in the reservoir as an endangered species form a good portion of the catch from the reservoir.

\section{Fisheries socio-economics}

The study identified gender inequity in reservoir fishing in Peechi. Fishing activities were steered by active male members (fishers) of Peechi SC/ST fishery co-operative society. The educational profile indicated that the literacy rate of the fishers was $88 \%$ which was very low when compared to Kerala's average literacy rate of $93.91 \%$. Studies on family profile indicated a prominent and periodical shift from joint family to nuclear family system among fishers.

Livelihood income analysis estimated the mean monthly income of fishers from fishing as ₹103 in Peechi (₹1235 a year). The studies (Fig. 6) depicted that out of the 6 seasons observed, fishing was practised only during 4 seasons. After a period of abstinence from fishing for one season (pre-monsoon 2017), the fishery increased to almost thrice the previous period of fishing. This suggested for a possible intervention by practising fishing holidays in Peechi during lean months and substituting the lost income with alternative livelihood programmes. Various management strategies suggested by fishers in Peechi for the maintenance of the reservoir fisheries and betterment of fishers livelihood was evaluated using RFMI in this study (Table 7).

The analysis indicated that RFMI of Peechi was mainly driven by the technical drivers (score being 69.09).

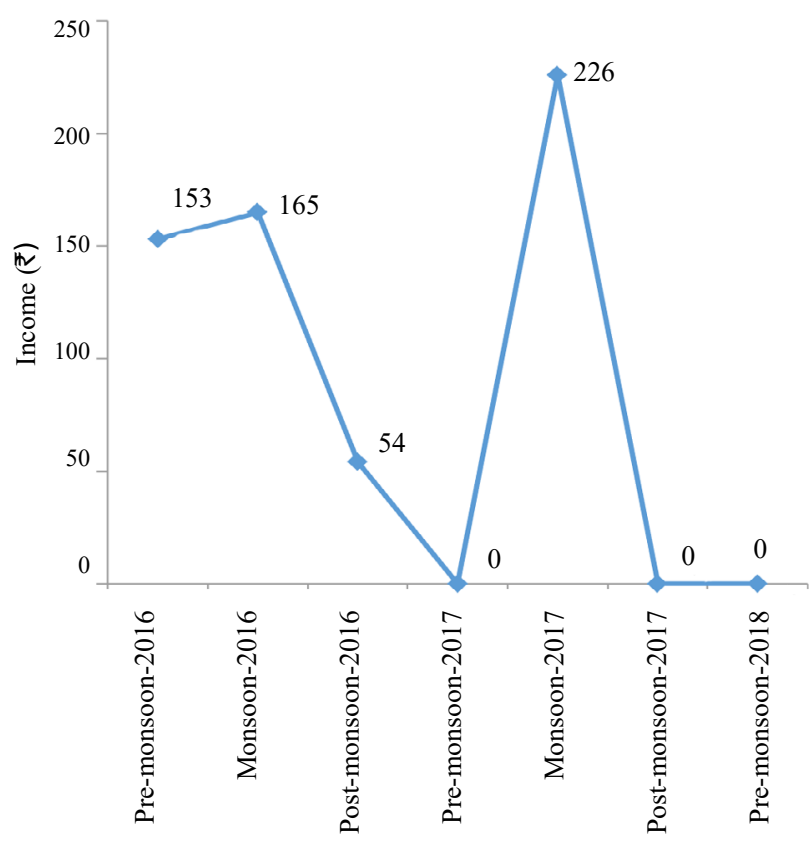

Fig. 6. Mean seasonal fishing income from Peechi Reservoir

Table 7. Reservoir fisheries management index (RFMI) of Peechi Reservoir

\begin{tabular}{ll}
\hline Drivers /Reservoir & Values \\
\hline Policy & 65.82 \\
Institutional & 52.73 \\
Social & 43.18 \\
Technical & 69.09 \\
Economic & 29.77 \\
Reservoir fisheries management index & 52.12 \\
\hline
\end{tabular}

The major technical attribute (Table 8) that contributed to RFMI was the fishers' support to continuous stocking of fishes in the reservoir and construction of hatcheries (score being 78.18). This indirectly indicated a need for alternate livelihood opportunities (construction of hatcheries) in the absence of stocking in the reservoir. The low prices of fishes (economic driver) to which the fishers were vulnerable in Peechi may be mitigated by adding value to the captured fishes on an entrepreneurial mode. The increased competitive nature of fishers (economic driver) created unprecedented juvenile fishery of the endangered $P$. mahecola which also calls for conservation of this fishery. Mesh size regulation and periodic closed seasons in fishing (technical driver) would help in mitigating the vulnerability faced by reservoir fishers. The procurement of fishers identity cards (score being 81.82) indicated their dire need for being enrolled in government sponsored 
schemes and subsidies exclusively meant for fishers (policy driver). The improved involvement of women in fishing operations (Table 8) and participation in decision making related to reservoir fisheries (social driver) would further raise the index leading the reservoir to be a model reservoir for the state. Alternate livelihood opportunities such as hatchery and tourism based business, cage culture activities involving E. suratensis during lean seasons (when fishing holidays were practised) will help in the sustainable increase in the livelihood of the reservoir fishers.

The study focused on identifying an appropriate management strategy for the upliftment of tropical reservoir fishers considering their socio-ecological vulnerabilities. Legal pluralism in reservoir management restricted the resource managers from harnessing the potential of such aquatic resources sustainably. The study also thus proves the essentiality of a comprehensive acknowledgement of all the resources associated with reservoir fisheries in bringing out the most appropriate management measure in a reservoir. Conservatory measures such as self-imposed regulatory fishing, practice of mesh size regulations along with the livelihood improvement strategies such as cage culture, hatchery operations and tourism are needed for the Peechi Reservoir fishery. Reservoir fishery management with respect to modifications in technical drivers would result in conceptualising a model fishery reservoir. The study emphasised the importance of planning at the level of the primary stakeholder for sustainable fisheries, which is otherwise referred to as a bottom up approach.

Table 8. Details of drivers used in Reservoir Fisheries Management Index (RFMI)

\begin{tabular}{|c|c|c|c|c|c|c|c|c|c|}
\hline \multicolumn{10}{|c|}{ Attributes of drivers used in RFMI } \\
\hline Social drivers & Score & Policy drivers & Score & Technical drivers & Score & Economic drivers & Score & Institutional drivers & Score \\
\hline $\begin{array}{l}\text { Membership } \\
\text { to women in } \\
\text { co-operative } \\
\text { society }\end{array}$ & 23.64 & $\begin{array}{l}\text { Requirement } \\
\text { of fisheries } \\
\text { policy }\end{array}$ & 32.73 & $\begin{array}{l}\text { Implementation } \\
\text { of minimum } \\
\text { legal size }\end{array}$ & 63.64 & $\begin{array}{l}\text { Low prices for } \\
\text { fishes }\end{array}$ & 87.27 & $\begin{array}{l}\text { Support of government } \\
\text { support in terms of } \\
\text { subsidy and other } \\
\text { financial benefits }\end{array}$ & 32.73 \\
\hline $\begin{array}{l}\text { Participation } \\
\text { in fishing } \\
\text { operations }\end{array}$ & 41.82 & $\begin{array}{l}\text { Acceptance } \\
\text { of mesh size } \\
\text { regulation }\end{array}$ & 70.91 & $\begin{array}{l}\text { Refrain from } \\
\text { fishing during } \\
\text { breeding season }\end{array}$ & 74.55 & $\begin{array}{l}\text { Alternative } \\
\text { marketing facility }\end{array}$ & 23.64 & $\begin{array}{l}\text { Trainings from research } \\
\text { institutions/state fisheries } \\
\text { departments on advanced } \\
\text { fishing practices }\end{array}$ & 72.73 \\
\hline $\begin{array}{l}\text { Participation } \\
\text { in hatchery } \\
\text { operations }\end{array}$ & 36.36 & $\begin{array}{l}\text { Receipt of } \\
\text { minimum } \\
\text { support price }\end{array}$ & 69.09 & $\begin{array}{l}\text { Refrain from } \\
\text { growth } \\
\text { overfishing }\end{array}$ & 78.18 & $\begin{array}{l}\text { No competition } \\
\text { among fishers }\end{array}$ & 21.82 & $\begin{array}{l}\text { Regular participation } \\
\text { in awareness campaign } \\
\text { conducted by various } \\
\text { institutes }\end{array}$ & 52.73 \\
\hline \multirow[t]{8}{*}{$\begin{array}{l}\text { Participation } \\
\text { in reservoir } \\
\text { based decision } \\
\text { making }\end{array}$} & 70.91 & $\begin{array}{l}\text { Promotion } \\
\text { of reservoir } \\
\text { fisheries by } \\
\text { government }\end{array}$ & 74.55 & $\begin{array}{l}\text { Supporting } \\
\text { continuous } \\
\text { stocking } \\
\text { of fishes }\end{array}$ & 78.18 & $\begin{array}{l}\text { No alternative } \\
\text { livelihood option }\end{array}$ & 32.73 & & \\
\hline & & $\begin{array}{l}\text { Procurement } \\
\text { of fishermen } \\
\text { identity card }\end{array}$ & 81.82 & $\begin{array}{l}\text { Construction } \\
\text { of hatcheries }\end{array}$ & 78.18 & $\begin{array}{l}\text { Easy availability } \\
\text { of loans }\end{array}$ & 25.45 & & \\
\hline & & & & $\begin{array}{l}\text { Stocking of } \\
\text { exotic fishes }\end{array}$ & 60.00 & $\begin{array}{l}\text { Easy repayment of } \\
\text { loans }\end{array}$ & 27.27 & & \\
\hline & & & & $\begin{array}{l}\text { Stocking fishes } \\
\text { more than } \\
100 \mathrm{~mm} \text { size }\end{array}$ & 67.27 & Price fixation & 87.27 & & \\
\hline & & & & $\begin{array}{l}\text { Emphasis on } \\
\text { diversity aspects } \\
\text { hindering stocking }\end{array}$ & 52.73 & & & & \\
\hline & & & & $\begin{array}{l}\text { Supporting } \\
\text { dredging in } \\
\text { reservoir }\end{array}$ & 69.09 & & & & \\
\hline & & & & $\begin{array}{l}\text { Implementing } \\
\text { cage culture }\end{array}$ & 69.09 & & & & \\
\hline & & & & $\begin{array}{l}\text { Motorisation } \\
\text { of crafts }\end{array}$ & 76.36 & & & & \\
\hline Total scores & 43.18 & & 65.82 & & 69.09 & & 29.77 & & 52.73 \\
\hline
\end{tabular}




\section{Acknowledgements}

Authors are grateful to the Director, ICAR-CIFRI, Barrackpore for his kind support and for the facilities provided.

\section{References}

Agostinho, A. A., Ferretti, C. M. L., Gomes, L. C., Hahn, N. S., Suzuki, H. I., Fugi, R. and Abujanra, F. 1997. Ichthyofauna from two reservoirs on the Iguacu River in different phases of colonization: Segredo and Foz of the sand. Segredo Reservoir: ecological bases for management, Maringa, EDUEM, p. 275-292 (In Portuguese).

Agostinho, A. A., Gomes, L. C. and Pelicice, F. M. 2007. Ecology and management of fishery resources in a Toori reserve in Brazil. EDUEM, Maringa. (In Portuguese).

APHA. 2012. Standard methods for examination of water and wastewater, $22^{\text {nd }}$ edn. American Public Health Association, Washington DC, USA, $1360 \mathrm{pp}$.

Biswas, S., Dinesh babu, A. P., Thomas, S. and Salian, T. S. 2016. GIS and its applications in Marine fisheries conservation and management in Karnataka, India. ESRI India Regional User Conference, Hyderabad.

Braveman, P. and Gottlieb, L. 2014. The social determinants of health: It's time to consider the causes of the causes. Public Health Rep., 129 (1-suppl.2): 19-31. doi: 10.1177/00333549141291S206.

Clarke, K. R. and Gorley, R. N. 2015. Getting started with PRIMER v7. PRIMER-E: Plymouth Marine Laboratory, Plymouth, UK.

Doi, H., Chang, K. H., Ando, T., Imai, H., Nakano, S. I., Kajimoto, A. and Katano, I. 2008. Drifting plankton from a reservoir subsidize downstream food webs and alter community structure. Oecologia, 156(2): 363-371. doi: 10.1007/s00442-008-0988-z.

Dudgeon, D., Arthington, A. H., Gessner, M. O., Kawabata, Z. I., Knowler, D. J., Leveque, C., Naiman, R. J., Prieur-Richard, A. H., Soto, D., Stiassny, M. L. and Sullivan, C. A. 2006. Freshwater biodiversity: Importance, threats, status and conservation challenges. Biol. Rev., 81(2): 163-182. doi:10.1017/ S1464793105006950.

Fernando, C. H. and Holcík, J. 1991. Fish in reservoirs. International review of the entire hydrobiology and hydrography, , 76(2): 149-167 (In German).

Froese, R. and Pauly, D. 2018. FishBase. https://www.fishbase.se.

Garett, H. E. and Woodworth, R. S. 1969. Statistics in psychology and education. Vakils, Feffer and Simons Pvt. Ltd., Mumbai, India, $329 \mathrm{pp}$.

Hye, M. A and Alamgir, M. 1992. Investigation on the natural spawning of carps in Lake Kaptai. Bangladesh J. Zool., 20: 27-33.
IUCN 2017. The IUCN Red List of Threatened Species. Version 2017-1. https://www.iucnredlist.org/.

Joy, M. K. and Death, R. G. 2004. Predictive modelling and spatial mapping of freshwater fish and decapod assemblages using GIS and neural networks. Freshw. Biol., 49: 1036-1052.

Jyotishi, A. and Parthasarathy, R. 2007. Reservoir fisheries management experience of Tawa in Madhya Pradesh. Econ. Political Wkly., 42(5): 409-415.

Liswanti, N., Shantiko, B., Fripp, E., Mwangi, E. and Laumonier, Y. 2012. Practical guide for socio-economic livelihood, land tenure and rights surveys for use in collaborative ecosystem-based land use planning. Centre for International Forestry Research. Bogor, Indonesia, p. 89-90.

McIntyre, P. B., Catherine, A. R. L. and Carmen, R. 2016. River fisheries, food security and biodiversity. Proc. Natl. Acad. Sci., 113 (45): 12880-12885.

Miranda, L. E. 2001. A review of guidance and criteria for managing reservoirs and associated riverine environments to benefit fish and fisheries. In: Marmulla, G. (Eds.), Dams, fish and fisheries: Opportunities, challenges and conflict resolutions. Food and Agriculture Organisation of the United Nations, Rome, Italy, p. 91-138.

Nelson, J. S. 1994. Fishes of the world, $3^{\text {rd }}$ edn. John Wiley and Sons, Inc., New York, USA, 752 pp.

Nogueira, M. G., Ferrareze, M., Moreira, M. L. and Gouvea, R. M. 2010. Phytoplankton assemblages in a reservoir cascade of a large tropical - subtropical river (SE, Brazil). Braz. J. Biol., 70(3): 781-793.

Oliveira, E. F., Minte-Vera, C. V. and Goulart, E. 2005. Structure of fish assemblages along spatial gradients in a deep subtropical reservoir (Itaipu Reservoir, BrazilParaguay border). Environ. Biol. Fish., 72(3): 283-304. DOI:10.1007/s10641-004-2582-5.

Paul, T. T., Palaniswamy, R., Manoharan, S., Unnithan, U., Sarkar, U. K., and Safeena, P. K. 2017. Environmental variables and diversity index as a tool for management in tropical man-made lakes. Lakes Reserv. Res. Manag., 22(4): 390-402.

$\mathrm{R}$ Core Team 2020. $R$ : A language and environment for statistical computing. R Foundation for Statistical Computing, Vienna, Austria. https://www.R-project.org/.

Talwar, P. K. and Jhingran, A. G. 1991. Inland fishes of India and adjacent countries, Vol. 2. CRC Press, Boca Raton, Florida, USA, $541 \mathrm{pp}$.

Tasneem, S. 2011. Biodiversity of Ichthyofauna of Barul Reservoir, Nanded District, Maharashtra. Nat. Environ. Pollut. Tech., 10(3): 487-488. 
TerBraak, C. J. F. and Smilauer, P. 2002. CANOCO Reference Manual and CanoDraw for Windows User's Guide: Software for canonical community ordination (version 4.5). Microcomputer Power, Ithaca, New York, USA, 500 pp.
Thomas, S. and Abdul Azis, P. K. 1999. Status of reservoir fisheries in Kerala and strategies for development with special reference to the Peppara Reservoir, Kerala. Ecol. Environ. Conserv., 5(1): 51-54. 